\title{
Analysis of operating parameters of the aircraft piston engine in real operating conditions
}

ARTICLE INFO

Received: 6 August 2021

Revised: 26 August 2021

Accepted: 1 September 2021

Available online: 13 September 2021

The article presents the results of analysis of operational parameters of piston engine CA 912 ULT which is a propulsion system of ultralight gyroplane Tercel produced by Aviation Artur Trendak. Research was conducted under normal operating conditions of the autogyro and data was collected from 20 independent tests including a total of 28 flight hours, divided into training flights and competition flights. Engine speed, manifold air pressure and temperature, fuel pressure, injection time, and head temperature were recorded at $9 \mathrm{~Hz}$ during each flight. Collective results were presented to show the statistical analyses of the individual parameters by determining the mean values, standard deviations and histograms of the distribution of these parameters. Histograms of operating points defined by both engine speed and manifold air pressure were also determined. Analyses of the engine dynamics as a distribution of the rate of change of the engine rotational speed were also carried out. It was shown that the engine operating points are concentrated mainly in the range of idle and power above 50\% of nominal power. The most frequent range is 70-80\% of nominal power. It was also shown that the dynamics of engine work in real operating conditions is small. It was also shown that the way of use significantly influences the distribution of operating points. During training flights, an increase in the number of take-offs and landings causes an increase in the amount of engine work at take-off and nominal power and at idle.

Key words: piston engine, engine parameters, statistic, normal operating conditions

This is an open access article under the CC BY license (http://creativecommons.org/licenses/BY/4.0/)

\section{Introduction}

Aviation is a rapidly developing sector, where the latest solutions are being introduced and modern technologies used [13]. Modern materials make it possible to reduce the aircraft empty weight, electronic systems improve flight safety, and introduction of electric and hybrid drives reduces the negative environmental impact [3]. However, the development of electric propulsion systems is still in its early stages, and most aircraft use internal combustion engines for propulsion $[6,17]$.

In order to meet the increasingly demanding requirements of both minimising engine weight and efficiency, engine components are being modified and their overall design optimised. This includes the shape of components as well as materials and manufacturing technologies.

One of the fastest growing branches of aviation is ultralight aviation, i.e. small, maximum two-seat aircraft with take-off mass not exceeding $600 \mathrm{~kg}[8,14]$. They are characterized by a short take-off and landing runway, possibility of using grass airfields, simplicity of operation and maintenance as well as simplified procedure for approval for production and use. Piston engines are most often used as propulsion systems. They are characterized by simplicity of construction, low inertia, low failure rate and low weight [11].

The development of ultralight aircraft propulsion systems is mainly aimed at increasing the power-to-weight ratio. The aim is to minimize the size and reduce the weight of engine components, while maintaining adequate power. Another solution is to increase power while maintaining or slightly increasing the weight of the engine. A common solution is therefore the turbocharging systems [10]. It allows to obtain higher power at similar weight. However it leads to increase of the mechanical and thermal load of the engine. This requires increased attention in operation and maintenance.

A fundamental aspect of aviation is safety. During operation, the pilot is obliged to constantly observe selected parameters of the propulsion unit and the whole aircraft. This allows early detection of damage or malfunction and appropriate action for safe further operation. For this purpose, on the aircraft are built appropriate sensors and instruments presenting the important parameters $[12,20]$.

The development of electronic systems has led to the replacement of analog instruments by electronic systems. This allows not only a better presentation of parameters but also their recording. This makes it possible to collect this information during normal operation and analyze it after the flight. These data can be used for example for optimization of propulsion units construction.

The availability of data allows to perform numerous studies on the distribution of engine performance under normal operating conditions. The authors of paper [1] show that the conditions of real operation significantly differ from the conditions of tests conducted as part of vehicle type approval. They showed that the differences between emissions in the test and in reality are significantly greater. It is also confirmed by the research conducted by $[9,21$, $23]$. With the authors of the paper [9, 23] focusing primarily on identifying differences in emissions between these conditions, the authors of the paper show as focusing on analyzing the causes of these differences [21]. They show that the difference lies primarily in dynamic conditions. 
This is also demonstrated by the authors of the work [4, 22] highlighting the significant contribution of dynamic states under normal vehicle operating conditions. They show that dynamic conditions occupy from $20 \%$ to $50 \%$ [22] of engine operating conditions in motor vehicles.

As demonstrated by the authors of paper, dynamic conditions significantly affect the propagation of the flame front [18] and thus the results of the combustion process [5]. It is therefore important to test engines under these conditions [14].

For aircraft engines or engines operating in hybrid assemblies, the contribution of dynamic conditions is much smaller [24]. As it was shown by the authors, it ranges from 5 to $20 \%$ of the engine operating time [25]. The difference also includes the average conditions of steady state engine operation. In the case of motor vehicles, the average conditions correspond to about $20-30 \%$ of the nominal power [2], while in the case of engines, they are much higher [25]. However, detailed analyses of the distribution of aircraft engine operating points under real operating conditions are lacking.

This paper presents an analysis of performance of modified Rotax - CA 912 ULT engine, used to propel the Tercel autogyro in real operating conditions.

\section{Methodology and research object}

\subsection{Research object}

The research was carried out on a Tercel autogyro with registration number SP-XXLX, produced by Aviation Artur Trendak company. It is a two-seat ultralight aircraft, designed for recreational, training, sport and demonstration purposes in ground visibility conditions. The Tercel autogyro is shown in Fig. 1. Table 1 presents basic technical data of the tested autogyro.

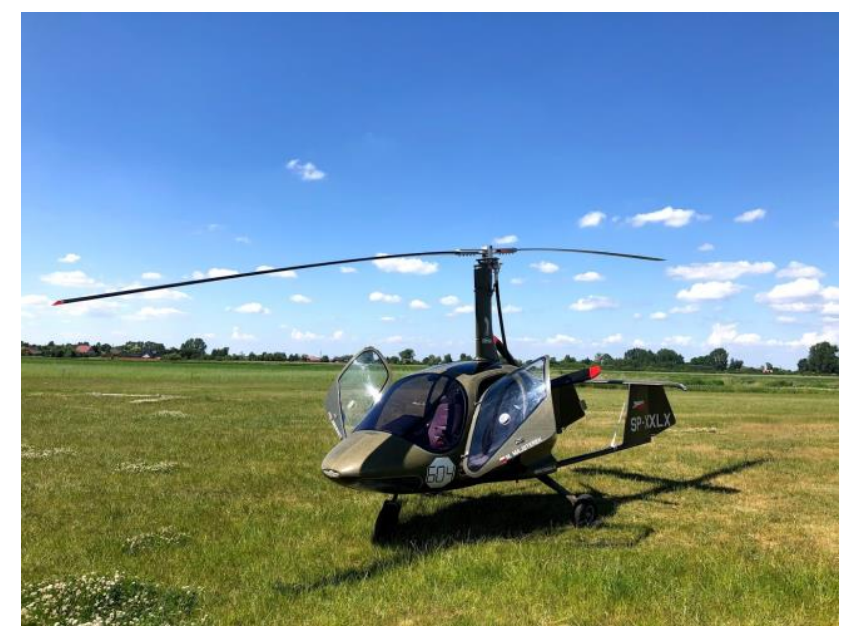

Fig. 1. Tercel autogyro produced by Aviation Artur Trendak

The Tercel is powered by a CA 912 ULT engine, which is a modification of the Rotax 912 engine most commonly used in ultralight aviation. The power supply system was rebuilt: two constant vacuum carburetors were replaced by multi-point port injection system. In addition, the engine was equipped with a turbocharger with an exhaust gas pressure control valve, allowing the maximum charge pressure to be limited. The technical data of the CA 912 ULT engine are shown in Table 2. Figure 2 shows the engine performance characteristics [26].

Table. 1 Technical data of Tercel autogyro [26]

\begin{tabular}{|c|c|c|}
\hline \multicolumn{3}{|c|}{ Dimensions } \\
\hline Rotor Diameter & 8.60 & $\mathrm{~m}$ \\
\hline Rotor Disc Area & 60.82 & $\mathrm{~m}^{2}$ \\
\hline Rotor blade chord & 0.20 & $\mathrm{~m}$ \\
\hline Overall length (without rotor) & 5.04 & $\mathrm{~m}$ \\
\hline Hull width & 2.35 & $\mathrm{~m}$ \\
\hline Cabin width & 2.20 & $\mathrm{~m}$ \\
\hline Cabin width & 1.36 & $\mathrm{~m}$ \\
\hline Overall height & 2.35 & $\mathrm{~m}$ \\
\hline Wheel diameter & 2.87 & $\mathrm{~m}$ \\
\hline \multicolumn{3}{|c|}{ Weight } \\
\hline Maximum take-off weight & 560 & $\mathrm{~kg}$ \\
\hline Empty weight & 295 & $\mathrm{~kg}$ \\
\hline Payload weight & 265 & $\mathrm{~kg}$ \\
\hline \multicolumn{3}{|c|}{ Propulsion System } \\
\hline Engine gear ratio & \multicolumn{2}{|c|}{$1: 2.43$} \\
\hline Propeller diameter & 1.72 & $\mathrm{~m}$ \\
\hline Propeller & \multicolumn{2}{|c|}{ KASPAR Aero 2/3 LT } \\
\hline Fuel tank capacity & 120 & 1 \\
\hline
\end{tabular}

Table. 2 Technical data of CA 912 ULT engine [26]

\begin{tabular}{|l|c|}
\hline Parameter & Value \\
\hline Cylinder no. & $4-$ boxer \\
\hline Displacement & $1211 \mathrm{~cm}^{3}$ \\
\hline Cylinder diameter & $79.5 \mathrm{~mm}$ \\
\hline Piston stroke & $61 \mathrm{~mm}$ \\
\hline Compression ratio & $9.0: 1$ \\
\hline Engine gear ratio & $2.43: 1$ \\
\hline Fuelling system & $\begin{array}{c}\text { Indirect, multipoint injection system } \\
\text { Auris by Auto\&Aero technologies }\end{array}$ \\
\hline Turbocharging & $\begin{array}{c}\text { Turbocharger with an exhaust gas } \\
\text { pressure control valve }\end{array}$ \\
\hline
\end{tabular}

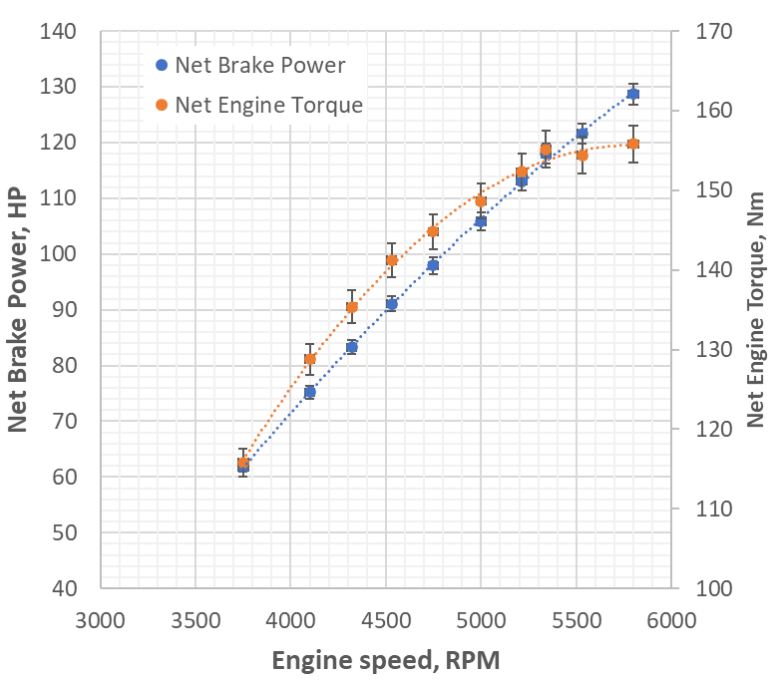

Fig. 2. Performance characteristics of the engine [26]

\subsection{Scope of research}

The aim of the study was to analyze the statistical distributions of the basic parameters of the aircraft engine operation in real operating conditions. The data acquisition system Flight Data Recorder FDR K.01 developed by Auto\&Aero Technologies Sp. z o.o. was used to carry out the tests. It collects the information sent from the avionics 
system and the fuel injection system via RS485 communication (Fig. 3).

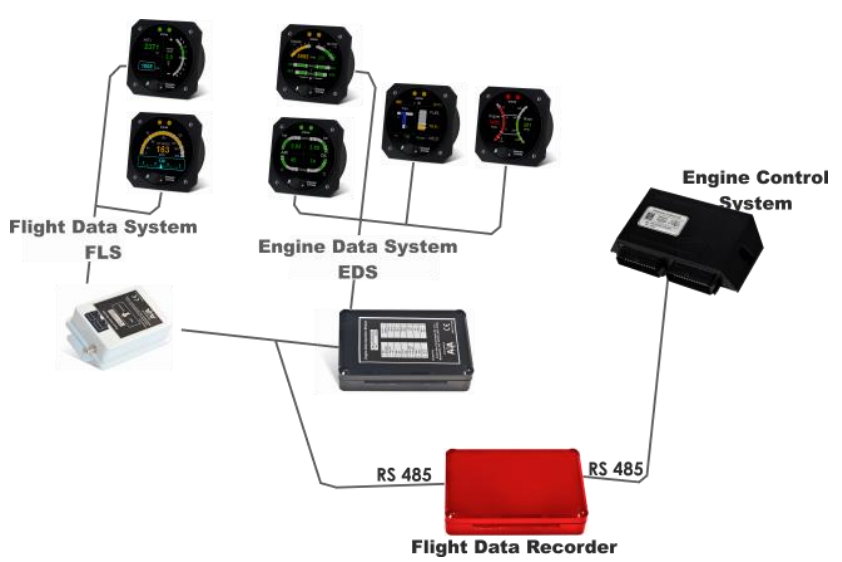

Fig. 3. Flight Data Recorder used in the research

The tests were conducted from 11.06.2021 to 22.06.2021. There were 20 independent tests (flights) divided into two types of tasks: training flights (Flying School) and flights during the competition (Sport Competitions). Training flights included mainly full Airfield traffic pattern with full landing or touch-and-go. The time to complete one Airfield traffic pattern was about 20 minutes and the time for a single recording ranged from 30 to 60 minutes. There were 14 flights with a total duration of 15 hours and 20 minutes during which a total of 37 take-offs and landings were made. Flights during the competition (Microlight Championships of Poland) included mostly distance flights lasting from 45 to 120 minutes. They included a total of 6 flights with a total duration of 12 hours and 45 minutes involving 6 takeoffs and landings. During the flights, the following parameters, among others, were recorded at $9 \mathrm{~Hz}$ :

- Air speed, km/h;

- Altitude, m. asl;

- Climb rate, $\mathrm{m} / \mathrm{s}$;

- Rotor speed, rpm;

- Crankshaft speed, rpm,

- Intake manifold pressure, $\mathrm{kPa}$,

- intake manifold air temperature, ${ }^{\circ} \mathrm{C}$,

- fuel pressure, $\mathrm{kPa}$,

- oil pressure, $\mathrm{kPa}$;

- oil temperature, ${ }^{\circ} \mathrm{C}$.

$-2 \times$ head temperature, ${ }^{\circ} \mathrm{C}$.

- $2 \times$ exhaust temperature, ${ }^{\circ} \mathrm{C}$.

\subsection{Methodology}

This article presents the results of statistical analysis of selected parameters obtained from all flights. The analysis included the engine operating point determined by two basic parameters: engine speed and manifold air pressure. To determine the dynamics of changes in operating conditions, the rates of changes of engine speed and manifold air pressure were determined. They were determined as the slope of the straight line approximated from consecutive 9 measurement samples. Data were grouped into two blocks: data from training flights (Flying School) and data from flights during the competition (Sport Competitions).

For each block of data statistical analyses were performed including determination of distributions of analyzed parameters. Results were presented as histograms. Additionally, analysis of two-dimensional distribution as a function of engine speed and manifold air pressure was performed.

\section{Analysis of results}

\subsection{Analysis of engine operating conditions}

Figure 4 shows the distribution of engine operating point rates during training flights (Flying School). The operating points are defined by engine speed and manifold air pressure. Two groups of operating points can be seen: the idle range $(\mathrm{n}=1500-2000 \mathrm{rpm}$ and $\mathrm{MAP}=20-40 \mathrm{kPa})$ and the heavy engine load $(n=4500-6000 \mathrm{rpm}$ and MAP $=$ $80-150 \mathrm{kPa}$ ). The highest frequent engine operating points occur at idle for 1500-2000 rpm and intake manifold pressure $30-40 \mathrm{kPa}$ and their rate is $14.2 \%$. In the case of higher engine loads, the highest frequency is $13.8 \%$ and occurs at $4500-5000 \mathrm{rpm}$ and MAP $=110-120 \mathrm{kPa}$, which corresponds to about $80 \%$ of the nominal engine power. There is also a significant occurrence of the engine starting power (n $=5500-6000 \mathrm{rpm}$ and MAP $=140-150 \mathrm{kPa}$ ) amounting to $4.5 \%$ in the studied flights. This power is used during takeoffs. A large part of engine work is also at nominal power $(\mathrm{n}=5000-5500 \mathrm{rpm}$ and MAP $=120-140 \mathrm{kPa})-$ it is about $11.3 \%$. It corresponds to the climb after take-off. A very small proportion of intermediate conditions is also evident.

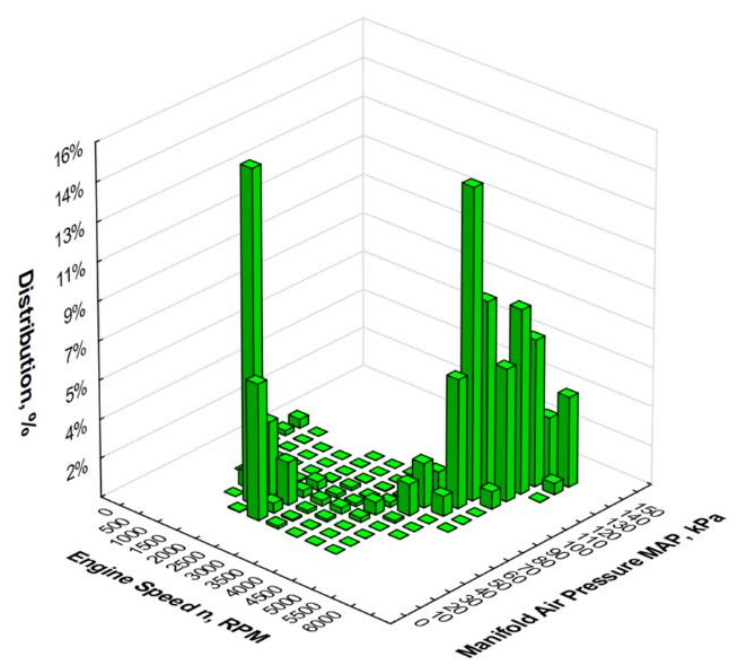

Fig. 4. Distribution of engine operating points during training flights

Figure 5 shows the analysis of engine operating points distribution for the flights during the sport competition. It can be seen that most of the time the engine was running at $\mathrm{n}=4500-5000 \mathrm{rpm}$ and MAP $=110-120 \mathrm{kPa}$. The engine worked at this point as much as $54.3 \%$ of the total engine operating time. The second most frequent point was the same rpm and lower MAP pressure $=100-120 \mathrm{kPa}$. The engine ran $26.2 \%$ at this point. Engine idling ( $\mathrm{n}=1500$ $2000 \mathrm{rpm}$ and MAP $=30-40 \mathrm{kPa}$ ) was only $5.4 \%$ and at takeoff power $1.8 \%$. Compared to the distribution for the 
training flights (Fig. 4), a significant concentration of operating points is evident, as well as measuring the idle and takeoff power section specific to the landing and takeoff stages.

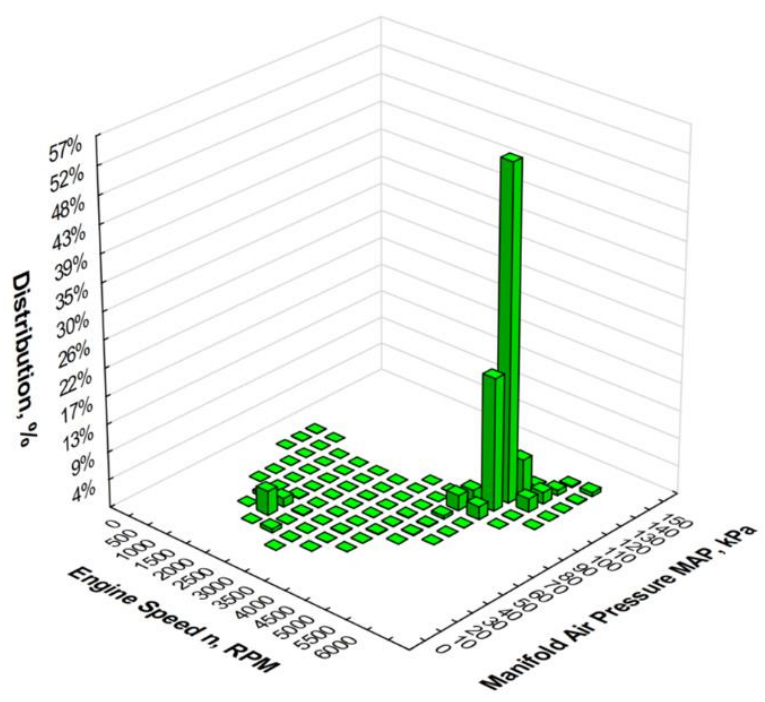

Fig. 5. Distribution of engine operating points during the sport competition

To further analyze the engine speed distribution, the analysis was performed with reduced intervals to $100 \mathrm{rpm}$ (Figs 6 and 7). For the training flights, the highest frequency of occurrence was a speed around $1800 \mathrm{rpm}$ corresponding to engine idle. The engine operated at this speed $12.9 \%$ of the total engine run time. The second most common speed range is around $4800 \mathrm{rpm}$. The $4700-4800 \mathrm{rpm}$ range is $8.4 \%$ and the $4800-4900 \mathrm{rpm}$ range is $8.1 \%$. These ranges correspond to a cruising power of about $75 \%$ of the nominal power of the engine. The next range is the rated power at 5300-5400 rpm and 5400-5500 rpm occurring at $6.9 \%$ and $6.2 \%$ respectively. The speed range $2000-2500 \mathrm{rpm}$, corresponding to the engine warm-up process, is also a significant part of the engine work and occupies a total of $9 \%$. This is due to short single flights, for which the warmup time is a significant part.

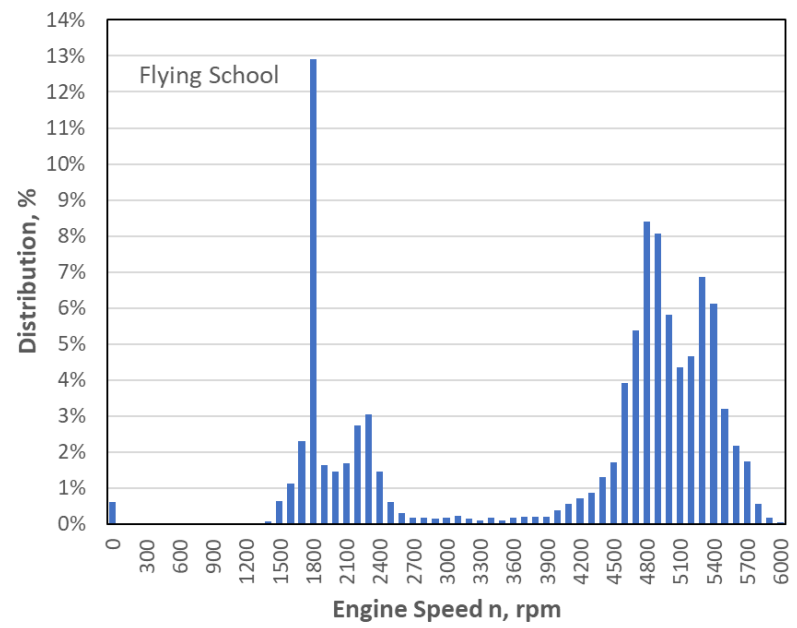

Fig. 6. Distribution of engine speed during training flights

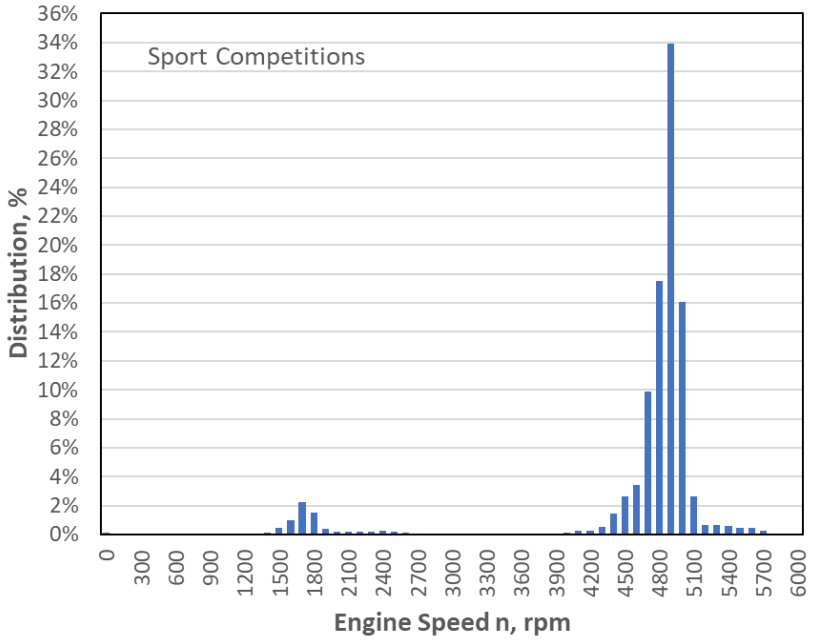

Fig. 7. Distribution of engine speed during the sport competition

For the sport competition flights (Fig. 7), the spread of engine speed occurrences is much smaller. Most of the time the engine was running in the $4700-4800 \mathrm{rpm}$ range: $34 \%$. This is the point corresponding to $75 \%$ of nominal power being the optimum flight speed for this model of autogyro. Due to the small number of take-offs and landings and the engine warm-up process, the speed ranges corresponding to these states occur much less frequently. Idle is only $4 \%$, warm-up is $1.5 \%$ and take-off power is $1.4 \%$.

Similar distributions are seen when the manifold air pressure is analyzed (Figs 8 and 9). For training flights (Fig. 8), the most common pressure is the $35-40 \mathrm{kPa}$ range corresponding to engine idle. This occurs for $14.5 \%$ of the engine operating time. The pressure ranges from 100 to 120 $\mathrm{kPa}$ occur with a similar frequency of about $6-8 \%$.

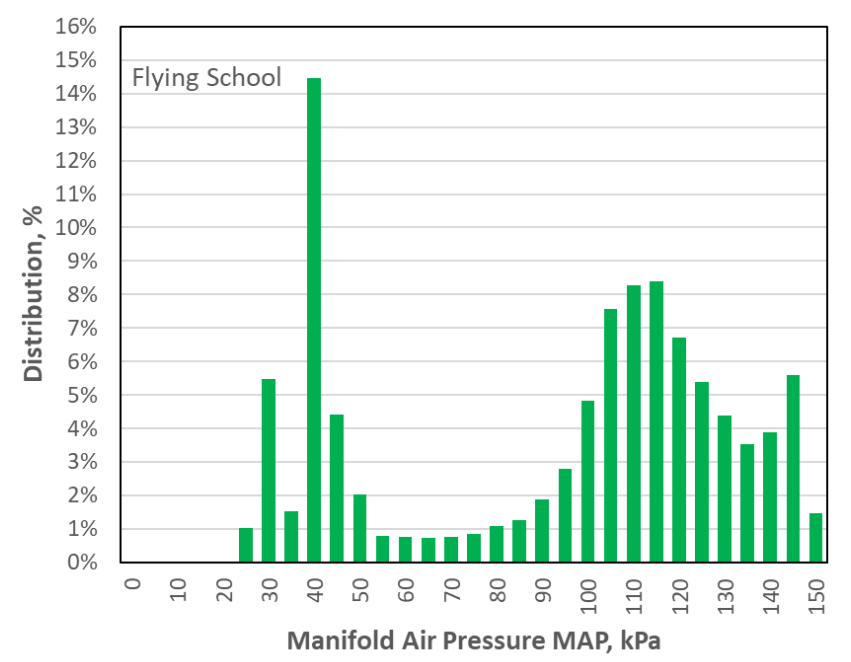

Fig. 8. Distribution of manifold air pressure during training flights

This range (100-120 kPa), on the other hand, dominates for flights during the sport competition. It occupies more than $50 \%$ of the engine operating time, with the range around $115-120 \mathrm{kPa}$ being the most represented (27.9\%). As with the previous analyses, a much smaller share of idle and take-off power is evident here as well. 


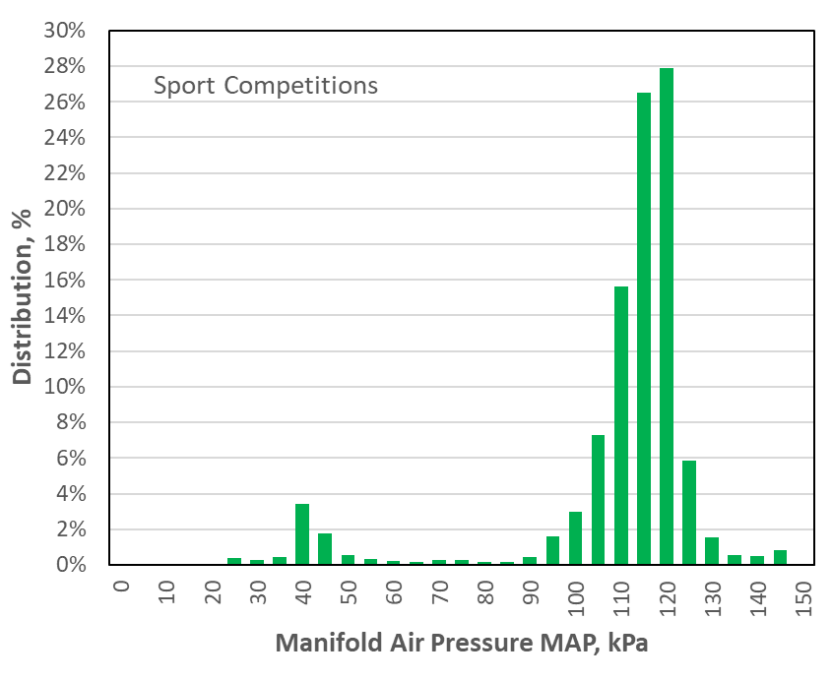

Fig. 9. Distribution of manifold air pressure during the sport competition

Another analysis included the rate of change of engine speed (Figs 10 and 11). For training flights (Fig. 10), more than $90 \%$ of the operating time is stable conditions in which the rate of change of engine speed does not exceed \pm 50 $\mathrm{rpm} / \mathrm{s}$. For competition flights (Fig. 11), 95\% of the engine operating time is within this range. For training flights, I stick out $1.8 \%$ of the values of decreases over $200 \mathrm{rpm} / \mathrm{s}$ and about $1.7 \%$ of increases above $200 \mathrm{rpm} / \mathrm{s}$. These values are due to the landing (taking off the throttle before landing) and takeoff (rapid addition of throttle) stages.

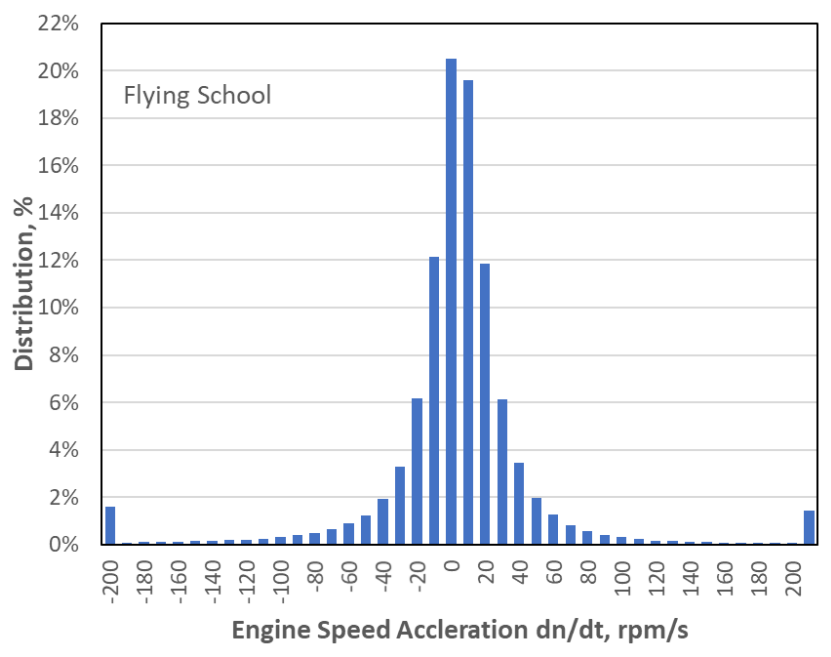

Fig. 10. Distribution of the rate of change of engine speed during training flights

For sport competition flights, these values occur much less frequently (Fig. 11). This is due to both fewer takeoffs and landings and a different, smoother control by the experienced pilot.

The stability of engine operating conditions is even more apparent when the rate of change of manifold air pressure is analyzed (Figs 12 and 13). For both groups of flights, the pressure practically does not change faster than $\pm 2 \mathrm{kPa} / \mathrm{s}$.

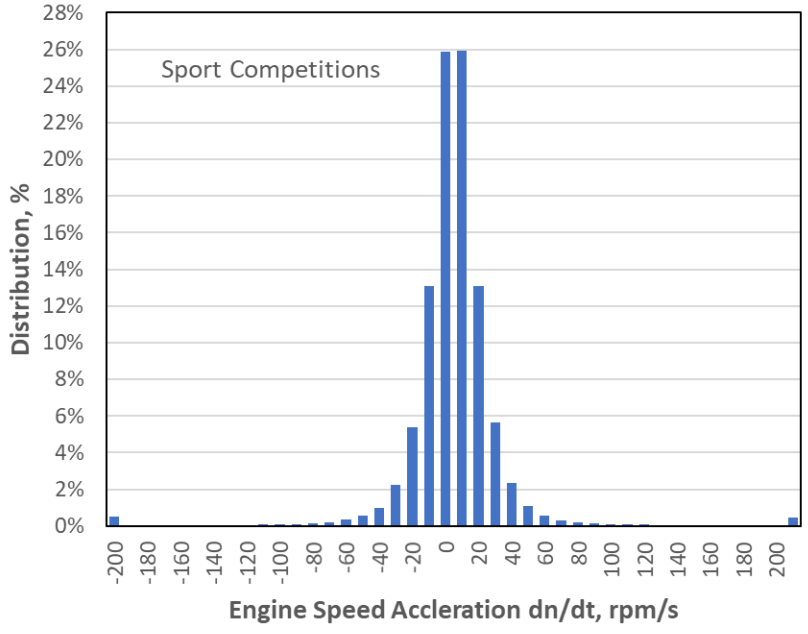

Fig. 11. Distribution of the rate of change of engine speed during the sport competition

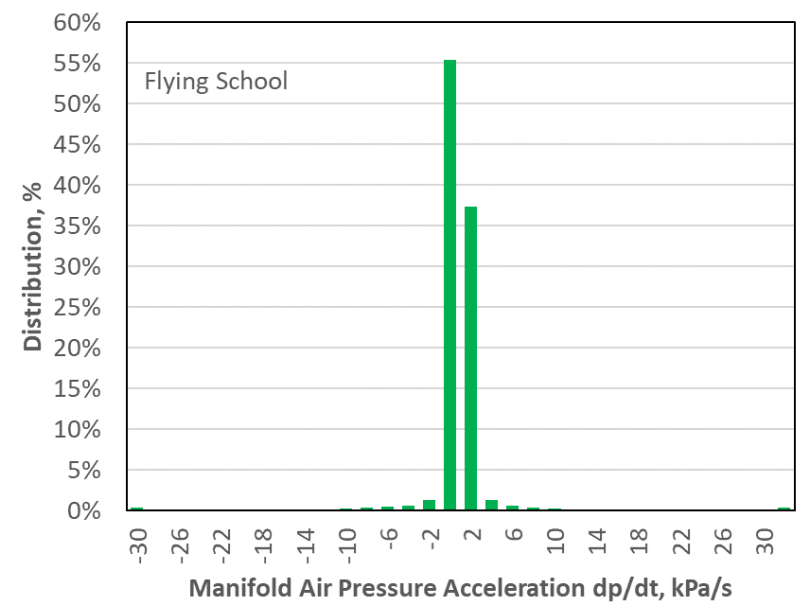

Fig. 12. Distribution of the rate of change of manifold air pressure during training flights

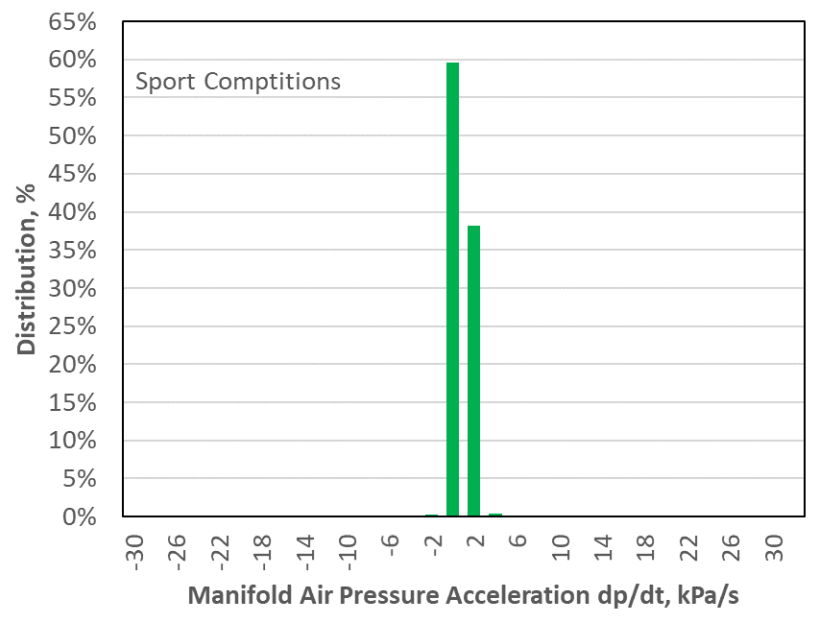

Fig. 13. Distribution of the rate of change of manifold air pressure during the sport competition

\section{Conclusions}

The following conclusions can be concluded from the study:

1) The aircraft engine is operated at predominantly steady state conditions. The speed does not vary more than \pm 50 
$\mathrm{rpm} / \mathrm{s}$ for $90 \%$ of the training flight time and $95 \%$ of the competition flight time. The difference in the rate of change of engine speed with different groups of flights shows that the transient conditions occur mainly during takeoff and landing.

2) Aircraft engines operate at average high loads. During the flights, the most common operating condition was an engine load of $70-80 \%$ of nominal power. For sport competition flights, this range covered more than $50 \%$ of the total engine operating time. The second most frequent operating condition of the engine is idling. Especially in the case of training flights, where it occupied $14 \%$ of the engine operating time. Small engine loads (below 50\%) practically did not occur during the research. Their share in the total engine operating time is marginal.
3) Takeoffs and landings strongly influence the engine operating point distribution. During takeoff and climb immediately after takeoff, the engine operates at takeoff power or nominal power while during landing it idles. This is due to the way windlasses are controlled, where the engine is switched to idle during descent to landing. In summary, the operation of an aircraft engine mainly consists of stable operation under heavy load.

\section{Acknowledgments}

This work was supported by the EU under the project No. PMA.01.02.00-14-9542/17, "Research and development on the design of a hybrid rotor drive at AVIATION ARTUR TRENDAK". within the framework of the European Regional Development Fund from the Regional Operational Program of Mazowieckie Voivodeship 2014-2020.

\section{Bibliography}

[1] ANDRYCH-ZALEWSKA, M., CHŁOPEK, Z., MERKISZ, J. et al. Evaluation of the test drive cycle conditions impact on exhaust emissions from an internal combustion engine. Combustion Engines. 2018, 175(4), 3-9.

https://doi.org/10.19206/ce-2018-401

[2] ANDRYCH-ZALEWSKA, M., CHŁOPEK, Z., MERKISZ, J. et al. Static internal combustion engine operating states in vehicle driving tests. Combustion Engines. 2019, 177(2), 5054. https://doi.org/10.19206/ce-2019-209

[3] BAKHOLDIN, D., BIRYUKOV, V., TOLSTOBROVA, L. Determining parameters of electric power unit for light aircraft. Advances in Engineering Research (AER). International Conference "Actual Issues of Mechanical Engineering" AIME. 2018, 157, 65-69. https://doi.org/10.2991/aime18.2018 .13

[4] BERA, P. Torque characteristic of SI engine in dynamic operating states. Combustion Engines. 2017, 171(4), 175180. https://doi.org/10.19206/ce-2017-429

[5] BIENIEK, A., BROL, S., MAMALA, J. The system for estimation parameters of internal combustion engine in the road test. Journal of KONES. 2011, 18(2), 279-286.

[6] CHŁOPEK, Z. Some remarks on engine testing in dynamic states. Combustion Engines. 2010, 143(4), 60-71. https://doi.org/10.19206/CE-117131

[7] CHŁOPEK, Z., BIEDRZYCKI, J., LASOCKI, J. et al. Assessment of the impact of dynamic states of an internal combustion engine on its operational properties. Eksploatacja i Niezawodność. 2014, 17(1), 35-41.

https://doi.org/10.17531/ein.2015.1.5

[8] CZARNIGOWSKI, J., WENDEKER, M., JAKLINSKI, P. et al. Model of injection system for SI radial aircraft engine. SAE Technical Paper 2007-01-1903. 2007. https://doi.org/10.4271/2007-01-1903

[9] GAO, Y., CHECKEL, M.D. Emission factors analysis for multiple vehicles using an on-board, in-use emissions measurement system. SAE Technical Paper 2007-01-1327. 2007. https://doi.org/10.4271/2007-01-1327

[10] GRABOWSKI, Ł., KARPIŃSKI, P., \& RUDZIK, D. Study on operating load of the compression ignition engine. Combustion Engines. 2017, 168(1), 168-171. https://doi.org/10.19206/ce-2017-127

[11] JAKLIŃSKI, P., WENDEKER, M., CZARNIGOWSKI, J. et al. The comparison of the operating parameters in an aircraft radial piston engine fuelled by 100LL and ES95 gasoline. Combustion Engines. 2009, 136(1), 52-59. https://doi.org/10.19206/CE-117220
[12] KIERNICKI, Z. Simulation method of operating parameters assessment used for engine comparative analysis. Combustion Engines. 2008, 132(1), 73-78. https://doi.org/10.19206/CE-117290

[13] KUŹNIAR, M. Energy comparative analysis of power units for use in light aircraft. Autobusy - Technika, Eksploatacja, Systemy Transportowe. 2019, 20(1-2), 88-92. https://doi.org/10.24136/atest.2019.013

[14] MAL'TSEVSLDI, V.V., GDANSKII, N.I. Simulation of the dynamics of drives under their real operating conditions. Chemical and Petroleum Engineering. 1997, 33, 269-271. https://doi.org/10.1007/BF02418471.

[15] MARKOWSKI, J. Correction of the model for assessing the emission of harmful exhaust emissions from the engine of a small aircraft during the flight. Transportation Research Procedia. 2018, 35, 230-239. https://doi.org/10.1016/j.trpro.2018.12.025

[16] MARKOWSKI, J., PIELECHA, J. Emission tests of the AI-14RA aircraft engine under real operating conditions of PZL-104 'Wilga' plane. Combustion Engines. 2009, 138(3), 64-70. https://doi.org/10.19206/CE-117180

[17] SITNIK, L. Statistic of fuel consumption in test and in natural operation of vehicles. Combustion Engines. 2017, 171(4), 239-244. https://doi.org/10.19206/CE-2017-440

[18] SURESHKUMAR, J., VENKITACHALAM, G., MALLIKARJUNA, J.M. et al. Study on effect of engine operating parameters on flame characteristics. SAE Technical Paper 2015-01-0749. 2015. https://doi.org/10.4271/2015-01-0749

[19] ERDMAŃSKI, M., SZYMANIEC, K. Performance characteristic of C-130E Hercules aircraft engine under variable work conditions. Combustion Engines. 2010, 142(3), 41-47. https://doi.org/10.19206/CE-117134

[20] WYSOCKI, O., KROPIWNICKI, J., CZYŻEWICZ, J. Analysis of the possibility of determining the general characteristics using the operational data of a vehicle engine. Combustion Engines. 2017, 171(4), 33-38. https://doi.org/10.19206/CE-2017-406

[21] RAHMAN, S.M.A., FATTAH, I.M.R., ONG, H.C. et al. State-of-the-art of establishing test procedures for real driving gaseous emissions from light- and heavy-duty vehicles. Energies. 2021, 14, 4195. https://doi.org/10.3390/en14144195

[22] SONG, J., CHA, J. Analysis of driving dynamics considering driving resistances in on-road driving. Energies. 2021, 14, 3408. https://doi.org/10.3390/en14123408

[23] ANDRYCH-ZALEWSKA, M., CHLOPEK, Z., MERKISZ, $J$. et al. Investigations of exhaust emissions from a combus- 
tion engine under simulated actual operating conditions in real driving emissions test. Energies. 2021, 14, 935.

https://doi.org/10.3390/en14040935

[24] BAI, M., YANG, W., SONG, D. et al. Research on energy management of hybrid unmanned aerial vehicles to improve energy-saving and emission reduction performance. International Journal of Environmental Research and Public Health. 2020, 17, 2917.

https://doi.org/10.3390/ijerph17082917

Jacek Czarnigowski, DSc., DEng. - Faculty of Mechanical Engineering, Lublin University of Technology.

e-mail: j.czarnigowski@pollub.pl

Karol Ścisłowski, MEng. - Faculty of Mechanical Engineering, Lublin University of Technology.

e-mail: k.scislowski@pollub.pl
[25] YUHIMENKO, V., BAIMEL, D., SITBON, M. et al. Hybrid internal combustion engine based auxiliary power unit. Micromachines. 2020, 11, 438.

https://doi.org/10.3390/mi11040438

[26] AVIATION ARTUR TRENDAK "Tercel Carbon RSTi Aircraft Maintenance Manual" Tercel-C-AMM-001-EN Edition 1, 28 Oct. 2020.

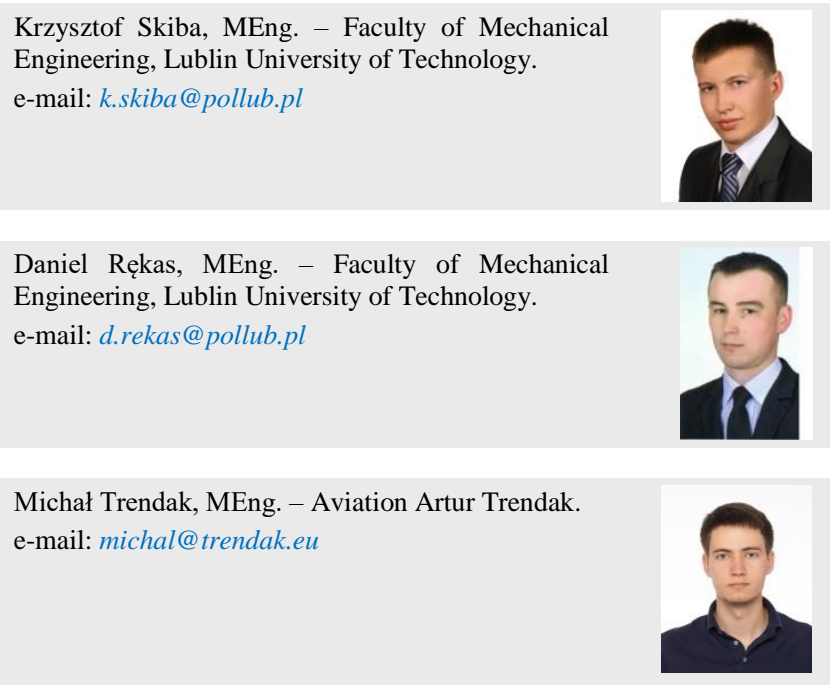

Engineering, Lublin University of Technology.

e-mail:d.rekas@pollub.pl

Michał Trendak, MEng. - Aviation Artur Trendak. e-mail:michal@trendak.eu
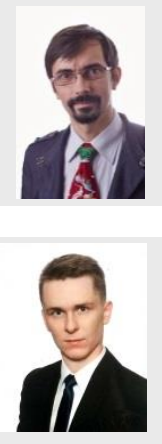